OPEN ACCESS

Edited by:

Terence C. Sunderland, University of British Columbia,

Canada

Reviewed by:

Margaret McCall Skutsch, Università Nazionale Autonoma del Messico, Mexico

Moira Michaela Maria Moeliono, Center for International Forestry

Research (CIFOR), Indonesia Erin O. Sills,

North Carolina State University, United States

*Correspondence: Colas Chervier colas.chervier@cirad.fr

Specialty section: This article was submitted to

People and Forests,

a section of the journal Frontiers in Forests and Global

Change

Received: 15 September 2019

Accepted: 24 September 2020

Published: 15 October 2020

Citation:

Chervier C, Piketty M-G and

Reed J (2020) A Tentative Theory of Change to Evaluate Jurisdictional Approaches to Reduced

Deforestation

Front. For. Glob. Change 3:498151. doi: 10.3389/ffgc.2020.498151

\section{A Tentative Theory of Change to Evaluate Jurisdictional Approaches to Reduced Deforestation}

\author{
Colas Chervier $^{1 *}$, Marie-Gabrielle Piketty ${ }^{1}$ and James Reed ${ }^{2,3}$ \\ ${ }^{1}$ Centre de Coopération International en Recherche Agronomique pour le Développement (CIRAD), Montpellier, France, \\ ${ }^{2}$ Center for International Forestry Research, Bogor, Indonesia, ${ }^{3}$ University of Cambridge Conservation Research Institute, \\ Cambridge, United Kingdom
}

Sub-national jurisdictions are promoted as strategic levels of governance for achieving reduced deforestation objectives. Jurisdictional approaches (JA) emerged as government-led, holistic approaches to forest and land use management across one or more legally defined territories. Despite increasing popularity amongst the science and practitioner communities, there is a lack of robust empirical data documenting their effectiveness in delivering environmental, social and economic outcomes. In this paper, we contend that further clarification of the JA concept would help its evaluation. More specifically, we suggest that current evaluation practices of JA would be strengthened if they were based on a theory of change clarifying the causal linkages between the interventions associated with a given JA and their effects. By integrating select empirical knowledge on JA with a selection of middle-range theories from the literature on collective environmental governance, we design a generic theory of change for $\mathrm{JA}$, which is articulated around two intermediary outcomes, namely the emergence of collaboration and social learning. We also formulate hypotheses regarding the conditions that enable or hinder these collective intermediary outcomes of JAs. We acknowledge that another fundamental challenge for JAs is to remove or block the external contradicting signals that still fundamentally drive deforestation. Thus, JA interventions need to operate not only at the jurisdictional level, but also beyond.

Keywords: evaluation, social learning, deforestation, jurisdictional approach, environmental collaborative governance

\section{INTRODUCTION}

The focus on tropical forests-and their contribution to climate change mitigation-is increasingly prominent in the international political agenda (Griscom et al., 2017; Seddon et al., 2019) as evidenced by recent commitments to the Sustainable Development Goals (halt deforestation by 2020), Bonn Challenge (restore $150 \mathrm{~m} \mathrm{Ha}$. by 2020) and Paris Climate Agreement (keep global temperature increase below $2^{\circ} \mathrm{C}$ ). In the latter, forests and natural solutions are considered to be able to provide up to one third of the mitigation required (Griscom et al., 2017).

Jurisdictional approaches (JAs) to holistically address forest and land use across one or more legally defined, primarily subnational, territories have recently gained global attention 
(Boyd et al., 2018). JAs have been proposed and implemented in various places because they were supposed to bring effectiveness gains in terms of deforestation reduction relative to approaches that are purely national, project-based or value-chain-based. The origin and enthusiasm for jurisdictional approaches is highlighted in the policy dialogue on Reducing Emissions from Deforestation and Degradation (REDD+) that evolved from pilot project implementation and national level readiness activities to subnational jurisdictional REDD+ programs (Fishman et al., 2017; Boyd et al., 2018; Hovani et al., 2018). JAs have also gained traction as a way to engage private companies committed to achieving zero deforestation supply chains (Wolosin, 2016). JAs origins can also be linked to landscape approaches (Paoli et al., 2016; Boyd et al., 2018) with which they share a number of principles (e.g., multi-stakeholder, multi-sector, multiobjective, landscape-scale) but use a different scope of action. The effectiveness promise of JAs primarily lies in the potential benefits gained from using government structures as a way, for example, to institutionalize change in land use rules, incentives or laws. Besides, the scale of JAs also makes it possible to work with specific, locally relevant causes of deforestation while achieving significant quantity of deforestation reduction and deforestation free commodities.

Implementation of JAs has been underway for over a decade and a recent study identified nearly 40 initiatives worldwide including the States of Acre and Mato Grosso in Brazil and the region of Madre de Dios in Peru (Stickler et al., 2018). However, despite increasing popularity amongst scientists and practitioners, there is a lack of robust empirical data documenting their effectiveness in delivering environmental, social and economic outcomes (Boyd et al., 2018; Hovani et al., 2018). The Nature Conservancy (TNC) concedes that "it is hard to know what jurisdictional programs did, when they did it, whether it had the intended impacts, and whether these results were greater than in comparable areas without jurisdictional programs" (Hovani et al., 2018). Emerging evaluations of jurisdictional REDD+, although not measuring their impact per se, suggest that they might fall short in delivering intended outcomes because they failed to engage important stakeholders or to remove important inconsistencies in the broader policy-framework (Bastos Lima et al., 2017; Rodriguez-Ward et al., 2018).

A major challenge to evaluation is that it remains relatively unclear what is meant by jurisdictional approach. "Heterogeneity of governance, cultural, and biophysical factors in jurisdictions as well as the changing context for jurisdictional programs has delayed conceptual development and creates a major challenge for retrospective evaluation. The sense of urgency to demonstrate the potential for landscape programs to contribute to global climate mechanisms often undermined careful documentation and clarification of how these programs work." (Hovani et al., 2018).

This paper contributes to addressing this challenge by designing a theory of change to evaluate JAs that integrates existing empirical knowledge on JAs and middle-range theories from the literature on collective environmental governance.

The literature reviewed to write this paper is based on a selection of scientific articles extracted from a search in Scopus database ${ }^{1}$, supplemented by a selection of key references from the gray literature ${ }^{2}$.

\section{WHY IS A THEORY OF CHANGE NEEDED TO EVALUATE JURISDICTIONAL APPROACHES?}

\section{Evaluation Practices of Jurisdictional Approaches}

Evaluation is commonly used to refer to impact evaluation. In this paper, we follow Patton (2018) and employ a broader definition of evaluation that also encompasses monitoring. Patton (2018) defines evaluation as a systematic process to determine merit, worth, value or significance of whatever is being evaluated (a program, policy, product, activity, etc.). Evaluation can serve different purposes (e.g., improve or reorient an intervention or inform decisions whether to continue, scale up or replicate an intervention) and can be performed through different approaches (Patton, 2008). Impact evaluation, which emphasizes causality between an intervention and its outcomes, is a particularly popular type of evaluation (Stern et al., 2012), including in the conservation sector (Baylis et al., 2016). However, strengthening results and impacts of an intervention can be achieved through other types of evaluation (Stern et al., 2012). For example, results monitoring can make significant contributions to supporting and reinforcing an intervention (Patton, 2008; Stern et al., 2012).

With this broad definition of evaluation in mind, we identified three types of evaluation that have been applied to JAs in the literature that we reviewed. Firstly, jurisdictional performance monitoring tools are currently gaining significant traction. The early call by Nepstad et al. (Nepstad et al., 2013a,b) to create such jurisdictional performance system was soon followed by the emergence of practical experiences including the Terpercaya initiative ${ }^{3}$ in Indonesia, the Landscale approach ${ }^{4}$, and the PCI (Produce, Conserve, Include) strategy in Mato Grosso, Brazil ${ }^{5}$. These tools generally list a number of indicators that are meant to be monitored in order to measure progress toward landscape or jurisdictional sustainability. These tools target multiple evaluation purposes. They help design more effective jurisdictional management practices; they provide relevant information to consumers, traders and investors willing to purchase or invest in sustainably produced commodities or to make green investment; and they can be used as criteria to design incentives, such as fiscal transfers, aimed at accelerating transitions toward sustainability. Overall, these strategies put a lot of emphasis on the identification of relevant, acceptable and

\footnotetext{
${ }^{1} \mathrm{We}$ used the following request: TITLE-ABSKEY [(jurisdiction* AND redd+) OR "jurisdictional approach*") AND (EXCLUDE (SUBJAREA, "MEDI")]. We selected articles that dealt with the evaluation of JAs.

${ }^{2} \mathrm{We}$ selected the references that drew lessons based on empirical experience or analysis and that aim to improve JA practice.

${ }^{3}$ http://www.euredd.efi.int/publications/demonstrating-and-promoting-districtlevel-sustainable-commodity-production

${ }^{4}$ https://www.landscale.org/

${ }^{5}$ http://pcimonitor.org/
} 
easily available metrics to assess outcomes of JAs. However, they do not generate evidence on causal links between interventions and outcomes.

Secondly, we found a few attempts to evaluate the impact of JAs or conservation policies targeting the jurisdictional scale and aimed at reducing deforestation. Scholars usually rely on counterfactual approaches and methods such as matching (Cisneros et al., 2015; Sills et al., 2017, 2020) and synthetic controls (Sills et al., 2015; Roopsind et al., 2019) to evaluate the impact of jurisdictional scale interventions (REDD+ incentives, blacklisting of municipalities in Brazil). Impact evaluation is mostly used for summative purposes, i.e., to check whether money has been spent for something and to subsequently inform decisions to replicate or scale up such interventions (Ferraro, 2009; Sills et al., 2017). Counterfactual approaches provide credible evidence for causality between an intervention and an outcome because they are based on the construction of a realistic comparison group that represents what would have happened if the target group of the intervention had not received the intervention. However, they generally fall short in providing evidence for the underlying mechanism and impact pathways, as they tend to focus on longer-term outcomes (e.g., deforestation, well-being, revenues, etc.). Furthermore, finding appropriate counterfactuals for evaluation objects such as JAs that are implemented at large scales remains difficult, particularly because of the small pool of potential controls (Sayer et al., 2017; Roopsind et al., 2019).

Finally, we identified a number of papers that evaluate the underlying processes of jurisdictional REDD+ with the aim to identify challenges, pitfalls and in turn improve outcomes (Ravikumar et al., 2015; Sanders et al., 2017; Rodriguez-Ward et al., 2018). These studies provide evidence for the influence of various governance aspects on jurisdictional REDD+ outcomes. Evidence for causal mechanisms is based on the triangulation of various data sources, including in particular semi-structured interviews with a large number of stakeholders and relevant secondary data. However, empirical knowledge about how JA work in practice and under what conditions remain scarce.

\section{Prerequisites for Implementing Theory-Driven Evaluations of JA}

There is a wide consensus in the evaluation literature regarding the importance of using theories of change to evaluate interventions (Astbury and Leeuw, 2010; Leeuw and Donaldson, 2015), particularly for complex interventions (Rey et al., 2011). A theory of change in evaluation generally articulates causal linkages between interventions and their desired effects. It also shows "how and why programs work (or fail to work) in different contexts and for different program stakeholders" (Astbury and Leeuw, 2010). The use of theories of change improves all three types of evaluation found in the reviewed literature on JA. For example, Miteva et al. (2012) argues that one of the major drawbacks of current impact evaluation studies is that "the empirical work is disconnected from theories that describe how the interventions affect outcomes." This limit affects both the internal validity i.e., the definition of the counterfactual (high risk of omitted variables) and external validity i.e., to what extent the results of the evaluation can be generalized (Miteva et al., 2012; Baylis et al., 2016). Theories of Change are also useful for the design of monitoring tools aimed at measuring the progress of conservation actions toward an intended goal (Margoluis et al., 2013).

We argue that, in the case of JAs, there are at least two components of theories of change that need to be strengthened. Firstly, there is a need to clarify the causal sequences of effects associated with the implementation of JA. We found limited evidence in the reviewed literature that JA empirical cases developed a clear vision on how things are supposed to unfold as a result of JA implementation in order to achieve deforestation reduction at the jurisdiction scale. In particular, there is no evidence that the most common jurisdictional performance monitoring tools are based on a clear theory of change. For example, Terpercaya indicators are "based on Indonesian laws and regulations and are aligned with the Sustainable Development Goals and the Paris Agreement on climate change." Links between the different indicators and the underlying assumptions are not explicit. Similarly, the PCI dashboard compiles several long-term indicators that are not explicitly embedded in a theory of change linking it with interventions. We found only one study that attempts to define theories of change for JA based on extended empirical knowledge gained from studying and implementing such approaches (Hovani et al., 2018). In this study, TNC produced a Theory of Change that clearly articulates intermediary outcomes showing "how improved cross-sector collaboration can translate into improved landscape performance and define enabling and hindering conditions for a number of causal links" (Hovani et al., 2018).

Secondly, there is a need to identify the specific mix of interventions implemented as part of JAs. In the early days of the literature on JAs, Nepstad et al. (2013b) advocated for strengthening linkages between three main types of interventions aimed at inducing emissions reduction from deforestation at the jurisdictional scale, namely REDD+, domestic policies and finance, and value chain initiatives. Recently, the gray literature has converged on the term "Jurisdictional Programs (JP)," defined as a range of multi-stakeholder interventions applied at subnational levels in order to achieve lasting, jurisdiction-wide improvements to natural resource management by catalyzing collaborative action by a group of stakeholders working with local government to institutionalize improved land governance and land use practices (Paoli et al., 2016; Hovani et al., 2018). Interestingly, these JPs encompass interventions that are generally not included or are marginally represented in classical typologies of conservation intervention (Lambin et al., 2014; Puri and Nath, 2016; Pirard et al., 2019). JPs typically focus on strengthening local governance by strengthening the network of actors, improving accountability, investing in knowledge development, etc. The other specificity of JPs is that it intends to cover a large scope of actors and policy domains. Furthermore, they span over long-time periods and are characterized by the emergence of new goals and interventions during the implementation phase. As a result, identifying the mix of interventions associated with a given 
JA is particularly challenging. Therefore, a theory of change, even if built retrospectively, can help describe such a system of interventions and justify the coherence between its components (Craig et al., 2008).

In order to extend ongoing work on JA theories of change and definition of JPs, we build on Leeuw and Donaldson's (2015) two types of theories in evaluation. According to these authors, the first type of theory "helps to understand the theories that underlie policy makers' and stakeholders' programs and policies" while the second type focuses on external, scientific theories that are capable of explaining the consequences of policies, programs, and evaluative actions (Leeuw and Donaldson, 2015). This second type of theory-building adds crucial insights about the mechanisms through which, and contexts under which, the causal sequence operates and allows putting into perspective the subjective insights provided by the professionals involved in these interventions (Leeuw and Donaldson, 2015). Building on the idea that both types need to be combined to draft meaningful theories, the rest of the paper presents an attempt to integrate current empirical knowledge on JA and middle-range theories from the literature on collective environmental governance into a generic theory of change.

\section{A PROPOSAL FOR A GENERIC THEORY OF CHANGE FOR JA}

In this section, we describe a generic theory of change chain for JA (Figure 1). We describe this theory of change from right to left, i.e., from the long-term impact to the short-term intermediate outcomes.

We consider the narrower cases of JAs, which aim at reducing deforestation as their long-run goal. However, following Hovani et al. (2018), we consider that this long-term impact is not a direct result of JAs. We argue that the direct outcome of JA is the formalization of a consistent and locally adapted framework of operational and collective rules (section "Formalization of a Framework of Rules"). We then suggest that formulating such a framework of rules necessarily involves multi-stakeholder collaboration across sectors and levels, and social learning (section "Effective Collaborative Processes"). In turn, both social learning and multi-stakeholder collaboration will only occur under some conditions (section "Conditions for Social Learning and the Multi-Stakeholder Collaboration"). We finally point to a number of intervention strategies that could comprise a jurisdictional program (section "Interventions").

\section{Formalization of a Framework of Rules Operational Rules}

The main contribution of JAs to reducing pressure on forests is the formalization of a consistent framework of operational rules such as incentives, policies, laws, and practices (Denier et al., 2015). These rules directly influence how decisions on natural resource management are taken (Ostrom, 2011). For example, in Acre, one of the flagship cases of Jurisdictional REDD+ that was integrated into state law, conditional incentives for ecosystem service conservation for indigenous peoples, local communities, smallholders and other land users (Da Conceição et al., 2015) were integrated into a policy mix that built on decades of forestbased development (Schmink et al., 2014).

The emergence of local operational rules as well as the main drivers of deforestation are influenced by the characteristics of the broader economic and political context outside the jurisdiction itself. It requires that inconsistencies in the broader national and international legal and policy framework are removed. In Acre and the Yucatan Peninsula, two jurisdictional REDD+ cases show that the success of sub-national initiatives "is hindered by the persistence of business-as-usual incentives stemming from the national level, and over which sub-national programs have little control" (Bastos Lima et al., 2017). It might also require linking the jurisdiction with existing higher-level incentives and rules for low emission development (Boyd et al., 2018).

\section{Collective Rules for Land-Use}

Achieving positive outcomes is contingent on stakeholders agreeing on a number of collective rules, i.e., rules that determine how operational rules are designed or revised (Ostrom, 2011). It includes a shared vision of goals for deforestation reduction, clarified rights and responsibilities, particularly tenure rights, a land-use plan clarifying underlying trade-offs, monitoring and reporting systems and grievance and conflict resolution mechanisms. Prior to creating its incentive program, Acre defined in 2007 an Ecological and Economic Zoning Plan that divides the province into geographic zones, regulates economic activities in previously deforested areas, and provides the basis for sustainable management in areas that remain forested (Secretaria and Ambiento, 2010). Such collective rules are amongst the progress indicators of major landscape governance assessment tools. For example, the Terpercaya indicators include sustainable land-use planning, complaint mechanism, customary rights recognition. The "Sustainable Landscapes Rating Tool" defines land use plan/zoning, clarity of land and resource tenure and use rights, monitoring and reporting systems, sustainable landscape goals as key enabling conditions for jurisdictional policies and governance that enable sustainable landscapes ${ }^{6}$.

More, to be actually enforced, locally defined land-use plans or tenure and use rights often require central government's recognition to become effective. For example, the Federal Government of Brazil approved the Acre's zoning plan before it was used to support the creation of the incentive program in the state (Stickler et al., 2018).

\section{Effective Collaborative Processes}

In the JA context, an effective process of rule creation should involve multi-stakeholder collaboration across sectors and levels, and social learning to formulate rules that are compatible with everyone's interests and that are context-specific (Paoli et al., 2016; Fishman et al., 2017; Hovani et al., 2018).

\section{Multi-Stakeholder Collaboration}

Multi-stakeholder collaboration across sectors and levels is well-emphasized in the subset of the JA literature reviewed

\footnotetext{
${ }^{6} \mathrm{https}: / /$ www.climate-standards.org/sustainable-landscapes-rating-tool/
} 


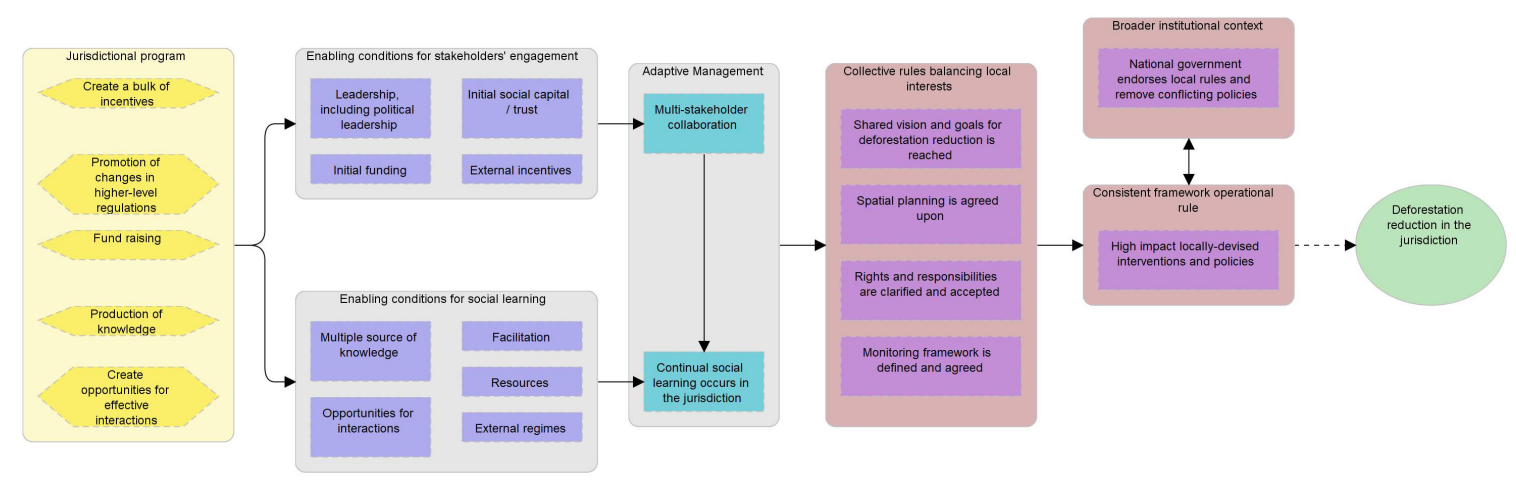

FIGURE 1 | Generic theory of change chain for JA drafted with Miradi software.

TABLE 1 | Key context-mechanism hypotheses for the emergence of collaboration in the case of Jas.

\begin{tabular}{|c|c|c|}
\hline Condition & Hypothesis & Key references \\
\hline Initial funding & $\begin{array}{l}\text { Partnerships are more likely to form when an existing institution has enough resources to } \\
\text { subsidize initial transaction costs (e.g., multi-stakeholder meetings, capacity building to } \\
\text { participate effectively, etc.). }\end{array}$ & Benson et al., 2013; Paoli et al., 2016 \\
\hline
\end{tabular}

(Paoli et al., 2016; Fishman et al., 2017; Rodriguez-Ward et al., 2018). It can be formalized through the creation of a multi stakeholder platform, but should anyway encompass the representatives of the various interest groups of a jurisdiction (Hovani et al., 2018). Fundamentally, cross-scale and crossborder collaboration is critical to engender collective rulemaking in this type of setting. Direct causes of environmental degradation-deforestation in particular-are the result of actions taken by various land users while solutions to solve this problem are often under the authority of different actors with a high degree of autonomy (Cash et al., 2006; Folke et al., 2007). Fishman et al. (2017) argue that the process of landuse planning in the context of JAs "needs to be participatory to ensure that the right delineations are selected, drawing on local expertise, and to ensure buy-in from stakeholders who will be expected to abide by the plan." In a JP setting, engagement of subnational government leaders is particularly crucial to be able to institutionalize change. Indeed, they are in a position to obtain the endorsement of changes in laws, plans and regulatory procedures, to strengthen law enforcement and to influence other key stakeholder's propensity to engage in JAs. Besides, the exclusion of important players at grass-root level is presented as a significant risk for JA success (Fishman et al., 2017; Rodriguez-Ward et al., 2018). In Madre de Dios, another case of jurisdictional REDD+ in Peru, effective integration of NonGovernmental Organizations (NGOs) and indigenous groups in decision-making was hindered by power imbalances and politics and proved to be an obstacle to the emergence of integrated landscape governance (Rodriguez-Ward et al., 2018).

\section{Social Learning}

Social learning is a core factor conducive to the emergence of adapted interventions and rules in JAs. Social learning is defined as a process characterized by a change in understanding 
TABLE 2 | Key context-mechanism hypotheses for social learning in the case of Jas.

\begin{tabular}{|c|c|c|}
\hline Condition & Hypothesis & Key references \\
\hline Multiple sources of knowledge & $\begin{array}{l}\text { Confrontation of multiple sources of knowledge, including expert and scientific knowledge } \\
\text { (e.g., expertise in geo-spatial information analysis, supply chain mapping, community } \\
\text { engagement, etc.), provides the material for critical and balanced assessment of the } \\
\text { collective problem and then co-production of knowledge for novel and socially robust } \\
\text { solutions. }\end{array}$ & $\begin{array}{l}\text { Schusler et al., 2003; Rist et al., 2007; } \\
\text { McCarthy et al., 2011; Paoli et al., } \\
\text { 2016; De Kraker, } 2017\end{array}$ \\
\hline Opportunities for interactions & $\begin{array}{l}\text { Opportunities for interactions-particularly between key stakeholders and relevant policy } \\
\text { makers and between different levels of government-support social learning, as they help } \\
\text { facilitate knowledge exchange and appreciation of other perspectives, deal with power } \\
\text { asymmetries and trade-offs, and strengthen trust. These outcomes are even stronger if } \\
\text { interactions are repeated, occur in small groups, and are unrestrained and open. }\end{array}$ & $\begin{array}{l}\text { Mostert et al., 2007; Muro and Jeffrey, } \\
\text { 2008; Cundill and Rodela, 2012; } \\
\text { Rodriguez-Ward et al., } 2018\end{array}$ \\
\hline Facilitation & $\begin{array}{l}\text { Bridging organizations help create social learning by playing the role of facilitators, as they } \\
\text { help build trust, manage conflicts, compile and generate knowledge, communicate } \\
\text { information, and mobilize broad support for change. }\end{array}$ & $\begin{array}{l}\text { Koontz, 2014; Koontz et al., 2015; } \\
\text { Paoli et al., 2016; Hovani et al., } 2018\end{array}$ \\
\hline Resources & $\begin{array}{l}\text { Adequate financial, human, and technological resources promote social learning, as they } \\
\text { enable participation in collaborative processes and the development of collective local } \\
\text { experience through the implementation of actions and monitoring and evaluation activities. }\end{array}$ & $\begin{array}{l}\text { Mostert et al., 2007; Rist et al., 2007; } \\
\text { Koontz et al., 2015; Paoli et al., 2016; } \\
\text { Fishman et al., } 2017\end{array}$ \\
\hline External regimes & $\begin{array}{l}\text { Effective social learning requires external regimes, particularly intervention of higher } \\
\text { government levels. They provide long-term stability and crucial resources, pressure } \\
\text { sub-national governments and private sector for change, and also create a certain degree } \\
\text { of autonomy and flexibility. }\end{array}$ & $\begin{array}{l}\text { Mostert et al., 2007; Pahl-Wostl et al., } \\
\text { 2007; Koontz et al., 2015; Hovani et al. } \\
\text { 2018; Rodriguez-Ward et al., } 2018\end{array}$ \\
\hline
\end{tabular}

TABLE 3 | Key intervention strategies for a jurisdictional program.

\begin{tabular}{|c|c|}
\hline Strategies & Example of actions \\
\hline \multirow[t]{2}{*}{ Fund raising } & Brokers mobilize sufficient initial funding. \\
\hline & $\begin{array}{l}\text { Subnational and national political leaders create a sustainable financing mechanism to cover recurrent costs of } \\
\text { collaboration and monitoring in particular. }\end{array}$ \\
\hline \multirow[t]{3}{*}{ Production of knowledge } & Brokers or research partners invest in integrated spatial databases and landscape analytics. \\
\hline & Brokers or research partners support the creation of a monitoring and evaluation system. \\
\hline & $\begin{array}{l}\text { Brokers create shared learning/consultation platforms to encourage knowledge co-production and synthesis } \\
\text { across knowledge holders. }\end{array}$ \\
\hline \multirow[t]{2}{*}{ Promotion of changes in higher-level regulations } & $\begin{array}{l}\text { Subnational political leaders/brokers advocate for changes in national regulations (recognizing local rules and } \\
\text { removing contradicting regulations). }\end{array}$ \\
\hline & $\begin{array}{l}\text { National government changes regulations so that laws recognize locally devised rules and removes } \\
\text { contradicting regulations. }\end{array}$ \\
\hline \multirow[t]{3}{*}{ Create a mix of jurisdictional scale incentives } & $\begin{array}{l}\text { Subnational political leaders/brokers advocate for the creation of incentives for sustainability, such as the } \\
\text { creation of sustainable sourcing partnerships with external value chain actors. }\end{array}$ \\
\hline & National government creates fiscal transfers conditional to the achievement of progress toward sustainability. \\
\hline & $\begin{array}{l}\text { Foreign governments create zero deforestation import strategies that take into account the progress of } \\
\text { commodity-producing jurisdictions toward sustainability. }\end{array}$ \\
\hline \multirow[t]{4}{*}{ Create opportunities for effective interactions } & Brokers create forums (e.g., multi-stakeholder platforms) and regularly convene stakeholders. \\
\hline & National or subnational authorities formally recognize these forums as decision bodies. \\
\hline & Civil society actors empower people to participate in decision making. \\
\hline & $\begin{array}{l}\text { Brokers or jurisdictional political leaders create or strengthen ties with external actors, particularly higher-level } \\
\text { government agencies, value chain actors, certification bodies, etc. }\end{array}$ \\
\hline
\end{tabular}

in the individuals involved and within wider social units or communities of practice that occur through social interactions and processes between actors within a social network (Reed et al., 2010). Social learning is particularly important in the case of JAs, because management decisions and plans have to be made in a context of high complexity and uncertainty and because JAs entail heterogeneity of actors and institutions in terms of power, needs, aspirations and interests (Armitage et al., 2009). TNC stresses that it is through social interactions that stakeholders can develop shared understanding of what is happening in the landscape, clarify their own goals and interests, learn about those of others, and strengthen trust. Eventually, this helps develop greater clarity on high-leverage interventions that are compatible with everyone's interests (Hovani et al., 2018).

\section{Conditions for Social Learning and the Multi-Stakeholder Collaboration Emergence of Collaboration}

We identified in the JA literature reviewed a number of enabling/hindering conditions influencing the emergence of collaboration. In order to clarify the underlying assumptions, we 
build on literature on the Institutional Rational Choice approach. Within this type of approach, rational actors will engage in collaborative solutions to common-pool resources or public good dilemmas if the benefits of the outcomes for them outweigh the transaction costs of collaboration (Schlager and Blomquist, 1996; Ostrom, 2007). In turn, the characteristics of the social-ecological system (i.e., the context) influence the level of costs and benefits of engaging into collaboration and subsequently the emergence of collaborative arrangements (Schlager and Blomquist, 1996; Ostrom, 2007). In Table 1, we specify the enabling conditions that are likely to influence JAs, the corresponding hypotheses about underlying mechanisms, and key references in the subset of Institutional Rational Choice and JA literature reviewed.

\section{Conditions for Social Learning}

The literature on adaptive governance of social-ecological systems also identifies a number of conditions of social learning and assumptions about the underlying mechanisms. We use this material to summarize the main conditions of social learning identified in the reviewed literature on JAs related to reducing deforestation, and clarify the hypothesis about the underlying mechanisms (Table 2).

\section{Interventions}

Clarifying these second-tier intermediary outcomes provides guidance to refine or at least justify the objectives and strategies of jurisdictional programs. In Table 3, we present a number of strategies found in the JA literature reviewed (Paoli et al., 2016; Fishman et al., 2017; Hovani et al., 2018; RodriguezWard et al., 2018) that different stakeholders, including stakeholders that are external to the jurisdiction, can undertake to enhance collaboration and social learning and, in turn, reduce deforestation at the jurisdictional level. These strategies are aimed at creating the appropriate conditions for engaging jurisdictional stakeholders in collaboration around the management of landuse and for sustained learning.

\section{CONCLUSION/DISCUSSION}

The current enthusiasm for jurisdictional approaches to reduce deforestation is mainly based on the promise of effectiveness gains, which are yet to be verified. In this paper, we contend that further clarification of the JA concept would help its evaluation. We suggest that current evaluation practices of JAs would be strengthened if they were based on a theory of change clarifying the causal linkages between the interventions associated with a given JA and its effects.

Our contribution is a generic theory of change based on the integration of select empirical knowledge on JAs with middle-range theories from the literature on collective environmental governance. Our generic theory of change for JAs is articulated around two central intermediary outcomesnamely the emergence of collaboration and social learningin order to achieve deforestation reduction through the development of a coherent set of locally devised collective and operational rules. The literature on social learning and on the emergence of collaborative arrangements for the management of natural resources proved to be helpful to clarify assumptions underlying the links between second and third-tier outcomes. We also highlight that the effectiveness of JAs depends on a number of local but also external conditions. A challenge for JAs is also to remove the external contradicting signals (e.g., commodity markets, national, and international policies) that are still fundamental in driving deforestation (Curtis et al., 2018). As such, a JP would need to consider processes not only at the jurisdictional level, but also beyond.

Our generic theory of change has several limitations that are intimately linked to the fact that it is rather general and based on quite a limited pool of documentary resources and empirical experiences. Firstly, the different assumptions attached to the conditions for social learning and collaboration may not be valid in every context and may need to be specified. For example, "social learning may take place in the absence of any planned participatory process" (Reed et al., 2010). Similarly, some studies have pointed to the limits of mainstream monitoring and evaluation approaches and scientific knowledge to serve pro-poor and pro-environmental change processes (Guijt, 2008; Koontz et al., 2015). Specific types of monitoring knowledge may have to be generated or scientific knowledge may need to be turned into usable knowledge in order to address specific local knowledge needs. Secondly, some conditions for collective action or social learning that have not been presented in this paper may also prove to be of crucial importance in some contexts. For example, the literature on common pool resources shows how important the resource characteristics are in explaining the emergence of successful collective management (Ostrom, 1990; Agrawal, 2001).

These limits call for further empirical research on the theory of change of JA. This could be achieved by improving our understanding of stakeholders' perspective of JA theory (type I theory in Leeuw and Donaldson, 2015) using participatory methods such as scenario-building or visioning exercises and participatory Theory of Change exercises (Romero et al., 2017; Sayer et al., 2017; Qiu et al., 2018). This work can also be completed by scientific studies aimed at testing hypotheses derived from the theoretical literature (type II theory in Leeuw and Donaldson, 2015). This kind of process can be relatively costly, and thus requires sufficient awareness about the importance of evaluation, as well as a minimum level of willingness to pay amongst implementing and donor agencies. It is a necessary investment, though, if we want to more accurately evaluate the conditions of effectiveness and realize the actual potential of JAs in contributing to reducing deforestation and promoting jurisdictional sustainability.

\section{AUTHOR CONTRIBUTIONS}

CC and MGP discussed the original idea of the manuscript. CC wrote the manuscript and lead the revisions. JR and MGP provided insightful comments and edited 
the language and scientific content of the manuscript at all stages. All authors contributed to the article and approved the submitted version.

\section{FUNDING}

This research was part of Priorities 5 and 18 of the CGIAR (Consultative Group on International Agricultural Research) Research Program on Forests, Trees and Agroforestry (FTA, http://foreststreesagroforestry.org). The funding partners that have supported this research include the CGIAR Trust Fund

\section{REFERENCES}

Agrawal, A. (2001). Common property institutions and sustainable governance of resources. World Dev. 29, 1649-1672. doi: 10.1016/S0305-750X(01)00063-8

Armitage, D. R., Plummer, R., Berkes, F., Arthur, R. I., Charles, A. T., DavidsonHunt, I. J., et al. (2009). Adaptive co-management for social-ecological complexity. Front. Ecol. Environ. 7:95-102. doi: 10.1890/070089

Astbury, B., and Leeuw, F. L. (2010). Unpacking black boxes: mechanisms and theory building in evaluation. Am. J. Eval. 31, 363-381. doi: 10.1177/ 1098214010371972

Bastos Lima, M. G., Visseren-Hamakers, I. J., Braña-Varela, J., and Gupta, A. (2017). A reality check on the landscape approach to REDD+: Lessons from Latin America. For. Policy Econ. 78, 10-20. doi: 10.1016/j.forpol.2016.12.013

Baylis, K., Honey-Rosés, J., Börner, J., Corbera, E., Ezzine-de-Blas, D., Ferraro, P. J., et al. (2016). Mainstreaming impact evaluation in nature conservation. Conserv. Lett. 9, 58-64. doi: 10.1111/conl.12180

Benson, D., Jordan, A., Cook, H., and Smith, L. (2013). Collaborative environmental governance: are watershed partnerships swimming or are they sinking? Land Use Policy 30, 748-757. doi: 10.1016/j.landusepol.2012.05.016

Boyd, W., Stickler, C., Duchelle, A. E., Seymour, F., Nepstad, D., Bahar, N. H. A., et al. (2018). Jurisdictional Approaches to Redd+ and Low Emissions Development: Progress And Prospects, Working Paper. Washington, DC: World Resources Institute.

Cash, D., Adger, W. N., Berkes, F., Garden, P., Lebel, L., Olsson, P., et al. (2006). Scale and cross-scale dynamics: governance and information in a multilevel world. Ecol. Soc. 11:8. doi: 10.5751/ES-01759-110208

Cisneros, E., Zhou, S. L., and Börner, J. (2015). Naming and shaming for conservation: evidence from the brazilian amazon. PLoS One 10:e136402. doi: 10.1371/journal.pone. 0136402

Craig, P., Dieppe, P., Macintyre, S., Michie, S., Nazareth, I., and Petticrew, M. (2008). Developing and evaluating complex interventions: the new medical research council guidance. Bmj 337:a1655. doi: 10.1136/bmj.a1655

Cundill, G., and Rodela, R. (2012). A review of assertions about the processes and outcomes of social learning in natural resource management. J. Environ. Manage. 113, 7-14. doi: 10.1016/j.jenvman.2012.08.021

Curtis, P. G., Slay, C. M., Harris, N. L., Tyukavina, A., and Hansen, M. C. (2018), Classifying drivers of global forest loss. Science 361, 1108-1111. doi: 10.1126/ science.aau3445

Da Conceição, R. H., Börner, J., and Wunder, S. (2015). Why were upscaled incentive programs for forest conservation adopted? comparing policy choices in brazil, ecuador, and peru. Ecosyst. Serv. 16, 243-252. doi: 10.1016/j.ecoser. 2015.10.004

De Kraker, J. (2017). Social learning for resilience in social-ecological systems. Curr. Opin. Environ. Sustain. 28, 100-107. doi: 10.1016/j.cosust.2017.09.002

Denier, L., Scherr, S., Shames, S., Chatterton, P., Hovani, L., and Stam, N. (2015). The Little Sustainable Landscapes Book: Achieving Sustainable Development Through Integrated Landscape Management. Oxford: Global Canopy Programme.

Ferraro, P. J. (2009). Counterfactual thinking and impact evaluation in environmental policy. New Dir. Eval. 2009, 75-84. doi: 10.1002/ev.297

Fishman, A., Oliveira, E., and Gamble, L. (2017). Tackling Deforestation Through a Jurisdictional Approach: Lessons from the Field. Gland: WWF. (www.cgiar.org/funders), CIRAD (Centre International de Recherche Agronomique pour le Développement) through its CRESI (Creativity and Scientific Innovation) funding program, and CIFOR (Center for International Forestry Research) through its Global Comparative Study on REDD+ (www.cifor.org/gcs) funded by the Norwegian Agency for Development Cooperation (Norad).

\section{ACKNOWLEDGMENTS}

We finally thank the three reviewers for their insightful comments.

Folke, C., Pritchard, J., Berkes, F., Colding, J., and Svedin, U. (2007). The problem of fit between ecosystems and institutions: ten years later. Ecol. Soc. 12:30. doi: 10.5751/ES-02064-120130

Griscom, B. W., Adams, J., Ellis, P. W., Houghton, R. A., Lomax, G., Miteva, D. A., et al. (2017). Natural climate solutions. Proc. Natl. Acad. Sci. U.S.A. 114, 11645-11650. doi: 10.1073/pnas.1710465114

Grolleau, G., and McCann, L. M. J. (2012). Designing watershed programs to pay farmers for water quality services: case studies of munich and New York city. Ecol. Econ. 76, 87-94. doi: 10.1016/j.ecolecon.2012. 02.006

Guijt, I. (2008). Assessing and Learning for Social Change: A Discussion Paper. Institute of Development Stsdies. Brighton: University of Sussex.

Hovani, L., Cortez, R., Hartanto, H., Thompson, I., Fishbein, G., Madeira, E. M. et al. (2018). The Role of Jurisdictional Programs in Catalyzing Sustainability Transitions in Tropical Forest Landscapes. Arlington, VA: Nature Conservancy.

Koontz, T. M. (2014). Social learning in collaborative watershed planning: the importance of process control and efficacy. J. Environ. Plan. Manag. 57, 1572-1593. doi: 10.1080/09640568.2013.82 0658

Koontz, T. M., Gupta, D., Mudliar, P., and Ranjan, P. (2015). Adaptive institutions in social-ecological systems governance: a synthesis framework. Environ. Sci. Policy 53, 139-151. doi: 10.1016/j.envsci.2015.01.003

Lambin, E. F., Meyfroidt, P., Rueda, X., Blackman, A., Börner, J., Cerutti, P. O., et al. (2014). Effectiveness and synergies of policy instruments for land use governance in tropical regions. Glob. Environ. Change 28, 129-140. doi: 10. 1016/j.gloenvcha.2014.06.007

Leach, W. D., and Pelkey, N. W. (2001). Making watershed partnerships work: a review of the empirical literature. J. Water Resour. Plan. Manag. 127, 378-385. doi: 10.1061/(ASCE)0733-94962001127:6(378)

Leeuw, F. L., and Donaldson, S. I. (2015). Theory in evaluation: reducing confusion and encouraging debate. Evaluation 21, 467-480. doi: 10.1177/ 1356389015607712

Lubell, M., Schneider, M., Scholz, J. T., and Mete, M. (2002). Watershed partnerships and the emergence of collective action institutions. Am. J. Polit. Sci. 46, 148-163. doi: 10.2307/3088419

Margoluis, R., Stem, C., Swaminathan, V., Brown, M., Johnson, A., Placci, G., et al. (2013). Results chains: a tool for conservation action design, management, and evaluation. Ecol. Soc. 18:22. doi: 10.5751/ES-05610-180322

McCarthy, D., Crandall, D., Whitelaw, G., General, Z., and Tsuji, L. (2011). A critical systems approach to social learning: building adaptive capacity in social, ecological, epistemological (SEE) systems. Ecol. Soc. 16:18. doi: 10.5751/ES04255- 160318

Miteva, D. A., Pattanayak, S. K., and Ferraro, P. J. (2012). Evaluation of biodiversity policy instruments: what works and what doesn't? Oxf. Rev. Econ. Policy 28, 69-92. doi: 10.1093/oxrep/grs009

Mostert, E., Pahl-Wostl, C., Rees, Y., Searle, B., Tàbara, D., and Tippett, J. (2007). Social learning in european river-basin management: barriers and fostering mechanisms from 10 river basins. Ecol. Soc. 12:19. doi: 10.5751/ES-01960120119

Muro, M., and Jeffrey, P. (2008). A critical review of the theory and application of social learning in participatory natural resource management processes. J. Environ. Plan. Manag. 51, 325-344. doi: 10.1080/09640560801977190 
Nepstad, D., Boyd, W., Stickler, C. M., Bezerra, T., and Azevedo, A. A. (2013a). Responding to climate change and the global land crisis: REDD+, market transformation and low-emissions rural development. Philos. Trans. R. Soc. Lond B. BioSci. 368:20120167. doi: 10.1098/rstb.2012.0167

Nepstad, D., Irawan, S., Bezerra, T., Boyd, W., Stickler, C., Shimada, J., et al. (2013b). More food, more forests, fewer emissions, better livelihoods: linking REDD+, sustainable supply chains and domestic policy in brazil, indonesia and colombia. Carbon Manag. 4, 639-658. doi: 10.4155/cmt.13.65

Ostrom, E. (1990). Governing the Commons: The Evolution Of Institutions For Collective Action. Cambridge: Cambridge University Press.

Ostrom, E. (2007). Institutional Rational Choice: An Assessment Of The Institutional Analysis And Development Framework. Theor. Policy Process. New York, NY: Perseus Books Group, 21-64.

Ostrom, E. (2011). Background on the institutional analysis and development framework. Policy Stud. J. 39, 7-27. doi: 10.1111/j.1541-0072.2010.00394.x

Pahl-Wostl, C., Craps, M., Dewulf, A., Mostert, E., Tabara, D., and Taillieu, T. (2007). Social learning and water resources management. Ecol. Soc. 12:5. doi: 10.5751/ES-02037-120205

Paoli, G. D., Palmer, B., Schweithelm, J., Limberg, G., and Green, L. (2016). Jurisdictional Approaches to Reducing Palm Oil DrivenDeforestation in Indonesia. Scoping Study of Design Considerations and Geographic Priorities. Bogor: Daemeter Consulting.

Patton, M. Q. (2008). Utilization-Focused Evaluation. Thousand Oaks, CA: Sage publications.

Patton, M. Q. (2018). Evaluation science. Am. J. Eval. 39, 183-200. doi: 10.1177/ 1098214018763121

Pirard, R., Wunder, S., Duchelle, A. E., Puri, J., Asfaw, S., Bulusu, M., et al. (2019). Effectiveness of Forest Conservation Interventions: An Evidence Gap Map (IEU Learning Paper No. 02, 2019). Incheon: Green Climate Fund Independent Evaluation Unit.

Puri, J., and Nath, M. (2016). International Initiative For Impact Evaluation (3ie), Bhatia, R., International Initiative For Impact Evaluation (3ie), Glew, L., World Wildlife Fund, Examining The Evidence Base For Forest Conservation Interventions, Evidence Gap Map Report 4. New Delhi: International Initiative for Impact Evaluation, doi: 10.23846/egm0004

Qiu, J., Game, E. T., Tallis, H., Olander, L. P., Glew, L., Kagan, J. S., et al. (2018). Evidence-based causal chains for linking health. Dev. Conserv. Actions. BioSci. 68, 182-193. doi: 10.1093/biosci/bix167

Ravikumar, A., Larson, A., Duchelle, A., Myers, R., and Tovar, J. G. (2015). Multilevel Governance Challenges In Transitioning Towards A National Approach for REDD+: Evidence From 23 Subnational REDD+ Initiatives. Int. J. Commons 9. London: Ubiquity Press.

Reed, M., Evely, A., Cundill, G., Fazey, I., Glass, J., Laing, A., et al. (2010). What is social learning? Ecol. Soc. 15:1. doi: 10.5751/ES-03564-1504r01

Rey, L., Brousselle, A., and Dedobbeleer, N. (2011). Logic analysis: testing program theory to better evaluate complex interventions. Can. J. Program. Eval. 26, 61-89.

Rist, S., Chidambaranathan, M., Escobar, C., Wiesmann, U., and Zimmermann, A. (2007). Moving from sustainable management to sustainable governance of natural resources: the role of social learning processes in rural india, bolivia and mali. J. Rural Stud. 23, 23-37. doi: 10.1016/j.jrurstud.2006.02.006

Rodriguez-Ward, D., Larson, A. M., and Ruesta, H. G. (2018). Top-down, bottomup and sideways: the multilayered complexities of multi-level actors shaping forest governance and REDD+ arrangements in madre de dios, peru. Environ. Manage. 62, 98-116. doi: 10.1007/s00267-017-0982-5

Romero, C., Sills, E. O., Guariguata, M. R., Cerutti, P. O., Lescuyer, G., and Putz, F. E. (2017). Evaluation of the impacts of Forest Stewardship Council (FSC) certification of natural forest management in the tropics: a rigorous approach to assessment of a complex conservation intervention. Int. For. Rev. 19, 36-49. doi: $10.1505 / 146554817822295902$

Roopsind, A., Sohngen, B., and Brandt, J. (2019). Evidence that a national REDD+ program reduces tree cover loss and carbon emissions in a high forest cover, low deforestation country. Proc. Natl. Acad. Sci. U.S.A. 116, 24492-24499. doi: 10.1073/pnas.1904027116
Sanders, A. J. P., Hyldmo, H. D. S., Prasti, H. R. D., Ford, R. M., Larson, A. M., and Keenan, R. J. (2017). Guinea pig or pioneer: translating global environmental objectives through to local actions in central kalimantan, indonesia's REDD+ pilot province. Glob. Environ. Change 42, 68-81. doi: 10.1016/j.gloenvcha.2016. 12.003

Sayer, J. A., Margules, C., Boedhihartono, A. K., Sunderland, T., Langston, J. D., Reed, J., et al. (2017). Measuring the effectiveness of landscape approaches to conservation and development. Sustain. Sci. 12, 465-476. doi: 10.1007/s11625016-0415-Z

Schlager, E., and Blomquist, W. (1996). Emerging theories of the policy. Polit. Res. Q. 49:22.

Schmink, M., Duchelle, A. E., Hoelle, J., Leite, F., D’oliveira, M. V. N., Vadjunec, J., et al. (2014). Forest Citizenship in Acre, Brazil: Forests Under Pressure - Local Responses to Global Issues, IUFRO World Series. Vienna: IUFRO.

Schusler, T. M., Decker, D. J., and Pfeffer, M. J. (2003). Social learning for collaborative natural resource management. Soc. Nat. Resour. 16, 309-326. doi: $10.1080 / 08941920390178874$

Secretaria, D. M., and Ambiento, D. A. (2010). Zoneamento ecologico-econômico do acre. Fase I Documento Sintese Escala 1:250.

Seddon, N., Turner, B., Berry, P., Chausson, A., and Girardin, C. A. J. (2019). Grounding nature-based climate solutions in sound biodiversity science. Nat. Clim. Change 9, 84-87. doi: 10.1038/s41558-0190405-0

Sills, E., Pfaff, A., Andrade, L., Kirkpatrick, J., and Dickson, R. (2020). Investing in local capacity to respond to a federal environmental mandate: forest \& economic impacts of the green municipality program in the brazilian amazon. World Dev. 129:104891. doi: 10.1016/j.worlddev.2020.10 4891

Sills, E. O., de Sassi, C., Jagger, P., Lawlor, K., Miteva, D. A., Pattanayak, S. K., et al. (2017). Building the evidence base for REDD+: Study design and methods for evaluating the impacts of conservation interventions on local well-being. Glob. Environ. Change 43, 148-160. doi: 10.1016/j.gloenvcha.2017. 02.002

Sills, E. O., Herrera, D., Kirkpatrick, A. J., Brandão, A., Dickson, R., Hall, S., et al. (2015). Estimating the impacts of local policy innovation: the synthetic control method applied to tropical deforestation. PLoS One 10:e0132590. doi: 10.1371/journal.pone.0132590

Stern, E., Stame, N., Mayne, J., Forss, K., Davies, R., and Befani, B. (2012). Broadening The Range Of Designs And Methods For Impact Evaluations (No. Working Paper 38). London: DFID, doi: 10.22163/fteval. 2012.100

Stickler, C., Duchelle, A., Ardila, J. P., David, O., Chan, C., Rojas, J. G., et al. (2018). The State Of Jurisdictional Sustainability: Synthesis For Practitioners And Policymakers. CIFOR, EII, GCF Task Force. Bogor: CIFOR.

Villamayor-Tomas, S., Thiel, A., Villamayor-Tomas, S., Fleischman, F. D., Ibarra, I. P., and van Laerhoven, F. (2014). From sandoz to salmon: conceptualizing resource and institutional dynamics in the rhine watershed through the SES framework. Int. J. Commons 8, 361-395. doi: 10.18352/ijc.411

Wolosin, M. (2016). Jurisdictional Approaches To Zero Deforestation Commodities. Gland: WWF.

Conflict of Interest: The authors declare that the research was conducted in the absence of any commercial or financial relationships that could be construed as a potential conflict of interest.

The reviewer MM declared a shared affiliation with one of the authors, JR, to the handling editor at time of review.

Copyright (c) 2020 Chervier, Piketty and Reed. This is an open-access article distributed under the terms of the Creative Commons Attribution License (CC BY). The use, distribution or reproduction in other forums is permitted, provided the original author(s) and the copyright owner(s) are credited and that the original publication in this journal is cited, in accordance with accepted academic practice. No use, distribution or reproduction is permitted which does not comply with these terms. 